\title{
Environmental Challenges in Indonesia: An Emerging Issue in the Social Study of Religion
}

\section{Frans Wijsen*}

Radboud University, the Netherlands

\begin{abstract}
One of the emerging issues in religious studies is the relationship between religion and the environment. This issue has conceptual, empirical, and practical dimensions. This article explores some of the completed and ongoing empirical research projects and asks what a social study of religion can contribute to the theory and practice of environmentalism in Indonesia, and what this signifies for future research in this field. It argues that the social study of religion can help to conceptualize religion as a social construct and move beyond reified understandings of religion. Scholars of religion can make them aware of the fact that on the one hand religion has an added value and makes a difference, and that on the other hand religion is complex, diverse, and ambiguous. For future research in this field, the article proposes to elaborate more on the ambivalence of religion and to use the dialogical self-theory to deal with the dilemma between norms and practices, the tension between theological and technological voices, the faithbased underpinnings of 'small' ('back to nature') and 'smart' (circular economy, green technology) solutions for ecological challenges, and the gap between the religion that is lived in every-day lives and the religion that is learned in schools and mosques, drawing on classical sources.
\end{abstract}

\section{Key Words}

Environmental issues, water management, waste management, Islam, social study of religion, Indonesia

\section{Introduction}

One of the emerging issues in religious studies is the relationship between religion and the environment (Bagir 2021). This issue has conceptual, empirical, and practical dimensions. What do religious leaders teach

\footnotetext{
* Corresponding author:

Frans Wijsen

Erasmusplein 16525 HT Nijmehen, the Netherlands.

Email: frans.wijsen@ru.nl
} 
about the relationship between humans and nature? How do believers conceptualize and interpret the ecological challenges and what solutions do they suggest? Which forms does faith-based environmentalism take? How do faith-based organizations position themselves in relation to governmental and other non-governmental actors in the environmental movement?

Indonesia is the third largest polluter in the world. There are quite some studies on environmentalism in Indonesia from a religious studies point of view. In this paper I do not address conceptual ("know how it is") and practical ("know how to do") issues such as what do religious sources teach about nature, and how can faith-based organizations make a difference in this field? Rather, I explore some of the completed and ongoing empirical research projects that I am involved in and ask what a social study of religion can contribute to the theory and practice of environmentalism in Indonesia, and what this signifies for future research in this field.

\section{The Project Framework}

Environmental degradation is a common challenge to the whole of humanity, and Indonesia is a major player in this respect both in terms of causes and solutions. Indonesia is the fourth largest country population-wise, and it has the second largest rainforest reserve in the world. It is named the third largest polluter, the second biggest contributor to waste, the second highest emitter of greenhouse gas, and the second biggest deforester of the world.

It has a population growth of $1,5 \%$ and an economic growth of $6 \%$ (before the COVID-19 pandemic). Jakarta alone produces 6.000 tons of garbage every day. Rivers such as Ciliwung and Citarum in West Java are heavily polluted by microplastics, chemicals, metals, and anti-biotics, causing health problems (Asian Development Bank 2016). Indonesia lost $80 \%$ of its forests. Forests affect climate with their carbon-absorbing superpowers. Trees absorb carbon dioxide as they grow, converting it into oxygen. Deforestation is one of the factors that cause climate change.

Indonesia is also a major player in international climate change negotiations. It was the first OPEC country to sign the Kyoto protocol in 2004. It hosted the United Nations Climate Conference in Bali in 2007, which produced the Bali roadmap that plays a role in the debates until today, promised to control greenhouse gas emission at a meeting of G20 leaders in 2009 (Jotzo 2012: 98), and at the United Nations Ocean Conference in New York in 2017 committed itself to reduce plastic waste by $70 \%$ in 2025 (Editorial Board 2019). 
Also in its domestic policy, the Indonesian government promotes green policies, despite various constraints. In 2014, the Indonesia Ministry of Environment published a report on "Environment Education in Indonesia" to implement environmental education in 250.000 schools and 3.000 universities, among them numerous Islamic institutions (Deputy for Public Participation 2014). And increasingly it urges religious leaders and faith-based organizations to play their part in promoting environmental awareness and nature-friendly behavior. Among others, it stimulates ecopesantren and eco-mosques.

Indonesia has the largest Muslim population in the world. According to Bagir and Martiam (2016), the issue of ecology does not occupy an important place yet in Islamic thought. This is because there is a tension between norms and practices in Islam. They argue "that one of the important keys to further Islam and ecology discourse is to pay more attention to the empirical study of living traditions and practices. Such studies have long existed but are not widely accepted because of narrow normative criteria about what makes an idea or a practice 'Islamic'. What needs to be explored is not (only) the consistency and coherence of an idea with canonical sources but how Muslim communities develop, justify, and defend eco-friendly practices, and form their ideas about Islam and ecology through their practices (Bagir and Martiam 2061:85).

This article is an attempt at such an exploration. It will do so from the perspective of the cognitive dissonance theory and elaborate on it from the perspective of the dialogical self theory. Cognitive dissonance theory assumes that people find dissonance between two or more cognitions, and between cognition and behavior unpleasant, and have a tendency to reduce the dissonance. An example is smoking. We know that smoking is unhealthy. When we are smokers, we will find arguments to justify our behavior or stop smoking (Festinger 1957). Dialogical self theory argues that inconsistency between cognitions and practices is not always experienced as unpleasant. The cognitive dissonance theory assumes that the self is homogeneous, however, according to the dialogical self theory it is not. The self is polyphonic and people can live with conflicting voices from a multiplicity of positions they take. As a rational consumer, I want to buy goods as cheap as possible; as an engaged Christian and citizen, I feel the responsibility to buy goods that are produced in an eco-friendly way to protect the earth and I am willing to pay a bit more. Thus, I shift between different I-positions and I dialogue with various voices in my 'self' (Hermans 2018). 


\section{Water, Health and Development}

As said above, the Citarum River in West Java is one of the most polluted rivers in the world. The national and provincial governments have had an integrated vision of river management since the early sixties of the previous century (Citarum Roadmap 2017). But, the practice of river management has been quite fragmented. To stimulate a sense of shared ownership, co-creation, and collaboration, in 2012 the Alliance for Water, Health and Development started a Netherlands-Indonesia multidisciplinary research network training eight doctoral students in the fields of water management, engineering, medicine, health science, international economics, development studies, cultural anthropology, and religious studies. The underlying idea was that water quality, health, and well-being are interrelated.

The research team realized that it could not solve the massive problem of pollution of Citarum River. It thought that it could make a modest contribution through the interdisciplinary training of future leaders in Indonesia. So every doctoral student had an Indonesian and a Dutch supervisor from two different disciplines. The team acknowledged that Indonesia has the largest Muslim population in the world and that more specialized knowledge about Indonesian Islam and its position on environmental issues was needed. This is how I got involved in the research team as a scholar of religion.

Together with an Indonesian professor in the field of water management, I supervised an Indonesian doctoral candidate who herself had a technical education and an Islamic background. Our contribution to the multidisciplinary research program was a project entitled Pollution of Citarum River and Purification in Islamic Thought (Wijsen \& Saptaningtyas 2016; Saptaningtyas 2020; Wijsen \& Saptaningtyas 2021). Our question was: how come the Citarum River is heavily polluted, while the people who live close to the river consider themselves to be Muslims and purity is a core value of Islam (Jotzo 2012)? Every day, approximately 400 tons of livestock waste, 25 thousand cubic meters of household waste, and 280 tons of industrial waste are disposed to Citarum River, partly because people do not care about the river, and partly because of the lack of good infrastructure in terms of waste disposal, mismanagement, and corruption.

Inspired by the tension between norms and practices (Bagir and Martiam 2016) and looking at it from the perspective of the cognitive dissonance theory (Festinger 1957) and the dialogical self theory (Hermans 2018), we conducted a comparative case study in a rural and 
an urban area. The rural area was represented by Kampung Mahmud, in Bandung Regency. The urban area was represented by Cigondewah Kaler, in Bandung Municipality. Both locations are historically linked. The residents claim that they are descendants of a saint, Eyang Mahmud. This is symbolized by a grave for Eyang Mahmud in both locations. From an economic point of view, the population of Kampung Mahmud is mainly made up of farmers, shopkeepers, and artisans. Cigondewah Kaler is less agricultural. Farmland has been sold to industries where people work as factory workers. There are also people who work for the government and there are local artists.

Religiously, people in Kampung Mahmud are traditional. The government has declared Kampung Mahmud a place of pilgrimage for pilgrims wishing to visit the saint's tomb, making the tomb a tourist attraction and source of income as well. In Cigondewah Kaler, industrialization and urbanization have transformed traditional spirituality. People generally have more money to spend and more people are able to go to Mecca for the compulsory pilgrimage, making the experience of Muslims a little more pan-Islamic.

On a conceptual level, we found that the religious voice dominated the other voices. Most interviewees in both case studies said there was "no relation" between purity in Islamic thinking and pollution of the Citarum River. Religious communities provide for the spiritual needs of the people, and water management is a concern of the government. So, at the conceptual level, we noted a secularization, a tendency to separate the sacred and the profane realms, also called "the rule of God" and "the rule of man". Only some scholars, artists, and activists in the urban site made a conceptual connection between religion and environment in the sense that they felt there should be a connection.

However, at the level of daily practice, most people did use religious beliefs and rituals. These are the "living traditions and practices" that Bagir and Martiam (2016) refer to, or everyday religion, not the religion that is learned in Islamic schools and mosques (Stringer 2008).

In the rural area, the interviewees, on the one hand, drew upon a technical voice, emphasizing the availability of groundwater by drilling wells. On the other hand, they referred to the religious voice. According to Islamic jurisprudence, pure water, which is water that can be used for ritual washing before prayer, is running water. The water in wells does not flow. However, people knew that they needed water from wells as an alternative to the water of the river. Again, according to Islamic jurisprudence, pure 
water does not smell, has no taste and color, but the water of the Citarum river does. It smells and sometimes it turns yellowish because it is used by textile factories to dyeing textile. So people performed a ritual at the tomb of Eyang Mahmud (tawasul) to ask the ancestors for permission to dig wells. The water from the well is pumped up to make it running water and thus pure according to Islamic jurisprudence.

In the urban area, the interviewees relied on common sense knowledge and what they called "religious science". Religious science is used to provide a local interpretation of Islamic tradition (hadith), combined with a technical view. To reduce the dilemma of using the polluted river water for the ritual purification before prayer, the local people pumped up the spring water through pipes to make running water, and they created a basin of water of two by two meters in size and thirty centimeters deep. If the amount of water in a basin is approximately 384 liters and does not smell, has no taste and color, it is pure according to regulations of Muslim scholars. So they used applied technology to adapt their water use to the prescriptions of Islamic jurisprudence.

Being aware that these are not long-term solutions, local activists and artists campaigned to clean up the river, combining local wisdom, Islamic thinking, and scientific views. Religious rituals from various traditions were used and freely mixed by some activists and artists to raise awareness and stimulate action. Before going to demonstrate against the government, demanding to clean up the river, a local artist of the Cigondewah Cultural Centre washed the feet of his mother to ask her blessing and drank the water. He implicitly referred to the washing of feet of his disciples by Jesus of Nazareth (John 13:2-5). The wastewater of washing his mother's feet was considered to be dirty water, but he used it as water that brings blessing, among others to show the power of rituals. Artists and activists also perform an annual keruh ritual in which they transform keruh (dirt) into ke-RUH, "towards the spirit".

We concluded that there are several mechanisms to relate perceptions of pollution and purification to daily practices that need water, namely suppression, compromise, and harmonization (Hermans 2018:317). Suppression occurs when one voice, e.g. the religious voice, is dominant and marginalizes other voices such as the medical and technical voices. Compromise occurs when people mediate between different voices and try to see overlaps between Islamic teachings, medical science, and technology. People harmonize when they look from a helicopter view and combine contrasting ideas into a more abstract idea that allows them to act in a way that is beneficial to them. The notion of "religious science", a combination 
of Islamic belief and logical reasoning, is an example of this. Thus, the inconsistency that the cognitive dissonance theory conceptualizes is not always experienced as unpleasant, and pollution is not always perceived as a disorder (Douglas 1966). It is coped with in a multiplicity of ways.

\section{Eco-Theology in Indonesian Islam}

In the above project, we focused on "living religion", that is, the religion outside the religious institutions. Perhaps that could explain the division between the spiritual and the material world because ordinary people prefer not to make statements about religious matters. They feel that they are not experts on religion and prefer to leave the decisions on religious matters to the religious leaders who have studied them.

Intrigued by the distinction between "the rule of God" and the "rule of man", we wanted to gain a deeper understanding of what happens within religious institutions (Aoki 2016). We started a new doctoral project conducting a comparative case study in the two largest Muslim organizations in Indonesia, Nadhlatul Ulama, and Muhammadiyah. The former claims to have 80 million members and the latter claims 60 million.

Since 2019, we have been studying the development of eco-theology in Indonesian Islam, and the rich vocabulary associated with it: eco-jihad, eco-fatwa, eco-dakwah, eco-halal, eco-pesantren, eco-mosque, and so on. This is a work in progress, but we found that there is a growing awareness of environmental issues in Islam and that there are efforts to close the gap between the "rule of God" and the "rule of man" (Mangunjaya 2015; Fahrurrazi 2019; Gade 2019).

It requires quite some reinterpretation in Islamic jurisprudence as most of the contemporary issues were unknown in the time of the Prophet Muhammad (PBUH). At that time, there were no microplastics, chemicals, metals, pesticides, and antibiotics in the water. Now, this is the case. Muslim scholars try to solve this by analogous reasoning and by using applied technology as we saw in the example of the wells.

In literature, Nadhlatul Ulama and Muhammadiyah are labeled as 'traditionalist' and 'modernist' (Gade 2019). We expected to find a deep ecology approach in Nadhlatul Ulama (a "back to nature" and "small is beautiful" attitude, a plea for environmental conservation and protection of nature) and eco-modernism (with an emphasis on green and clean technology, and circular economy) in Muhammadiyah. So far, we have found that these two attitudes do exist in Indonesian Islam, but that they are present in both organizations and thus do not coincide with any of them. It is a matter of emphasizing and balancing interests. 
One informant in the Nadhlatul Ulama case study gave "toll roads" as an example. Toll roads increase mobility and bring prosperity to people, but they also destroy nature because trees are cut. Thus, we have to balance economy and ecology. "Balancing" and "moderation" are keywords in the Islamic dealings with ecological issues (Central Board of Muhammadiyah 2016:32), balancing between 'small' and 'smart' solutions, between anthropocentric (ego-centric) and cosmocentric (eco-centric) visions, and the image of human beings as al-khalifa, the guardian and partner of nature, thus human beings as above nature, and humans and nature on equal footing.

\section{Plastic Waste in Islamic Boarding Schools}

Since 2018, the Water, Health and Development program that I mentioned above has entered a second phase under the name Living Labs Water Indonesia. A living lab is a research concept based on the notion of co-creation and shared ownership. It is defined, among others, as an "experimentation environment in which technology is given shape in real-life contexts and in which (end) users are considered "co-producers" (Ballon and Schuurman 2015).

Usually, green technologies are developed in the laboratories of universities, but they are not or hardly used by the people for whom they are intended, because they go beyond their imagination. For example, there are various techniques for purifying ablution water, but purified water is not used for ablution because people do not know or trust the technology behind the purifier. A Living Lab brings technicians, policymakers, and entrepreneurs to the users to see what their problems are and how they interpret them, what solutions are (technically) possible, (financially) feasible, and (culturally) acceptable.

Above I already referred to the pesantren ekologi. To gain a deeper understanding of the reinterpretation of Islamic jurisprudence, we decided to conduct an in-depth study of plastic waste in Pasuruan, East Java. This issue was explicitly mentioned by one of our informants in the project on eco-theology in Indonesian Islam. East Java is an interesting area as it is the cradle of traditionalist Islam. There is a disproportionate number of Islamic boarding schools. Some of them have a history dating back to the eighteenth century and a student population of twenty thousand or more. The Welang River flows through the area, which is just as polluted as the Citarum.

Out of a list of 58 brands of mineral water produced by Islamic organizations ("List Merk Air Minum 2020"), some of which are affiliated 
to Muhammadiyah or Nadhlatul Ulama, 7 come from Pasuruan Regency (Kabupaten Pasuruan). The water from Pasuruan is known for its high quality. The springs are located on the slopes of Mount Arjuna. Also, some Islamic boarding schools in Pasuruan, such as Pondok Pesantren Al-Yasini and Pondok Pesantren Sidori, produce mineral water as an income-generating project and distribute the water in plastic bottles. This is remarkable because Nadhlatul Ulama, the organization that they are affiliated with, has committed itself to reduce the use of plastic (Lamb 2018). So here again we look at the inconsistency between norms and practices.

In its 2019 meeting in Banjar, the National Conference of Religious Leaders (Musyawarah Nasional Alim Ulama [Munas]) within Nadhlatul Ulama discussed the disposal of plastic in the committee for discussion of contemporary religious issues, Bahtsul Masa'il ad-Diniyyah Waqi'iyyah (Mubarok 2019). It also discussed the depletion of wells and springs by commercial water companies, such as the producer of Aqua (a brand of the Danone company). Aqua is also located in Pasuruan and gets its water from the same sources as the pesantren in Pasuruan do. There is quite some competition between them.

In line with Islamic jurisprudence, the committee distinguished different attitudes towards waste. First, disposal of plastic waste is prohibited (haram) if it is manifestly (tahaqquq) or suspected (dzan) to be harmful to our health and environment. Second, disposal of plastic waste is discouraged (makruh) if the impact on health and the environment is small (tawahhum). Third, it is obligatory (fardhu) to obey the ban on disposal of plastic waste if the government has published a law on this (Fazin 2019). According to some of our informants, the religious leaders recommended the second attitude. Although plastic bottles are not harmful (mudharat) to our health and environment, the use of plastic must be reduced and littering of plastic waste must be discouraged (Syakir 2019). One informant spoke about "fasting", or refraining from needs created by the market, such as plastic. According to another informant, this advice should be better disseminated to the people so that it is followed up. And it has to be taken over by the state so that it becomes obligatory (fardhu). Fatwas do not have a legal basis as they only have a moral basis.

In the next stage of our research, we aim to conduct a comparative case study in a 'traditional' and a 'modern' pesantren, using the Living Lab approach. Based on the principles of shared ownership and co-creation, we bring the kyai, the chief executive officers of the cooperatives that produce and distribute the water (e.g. Koperasi Pondok Pesantren Sidogiri and Koperasi Konsumen Pondok Pesantren Al-Yasini), and industrial 
designers of technical universities together, to see if collaboratively they can do something to reduce the plastic waste in harmony with Nadhlatul Ulama's decree.

Many questions come up. How do religious leaders come to the conclusion that plastic is not harmful (mudharat) to our health and environment? How do they evaluate scientific evidence showing that there are microplastics in the water that endanger our health (Petrlik 2019) and that $70 \%$ of the plastic waste in Indonesia is burned which releases toxic gases that cause climate change? Are industrial designers able to develop eco-friendly bottles that are completely (using wood-fiber) or almost completely (using bio-plastic) degradable in a relatively short time? Are they able to produce them in cost-effective ways? Would religious leaders propagate the use of these alternatives? Are the chief executive officers able and willing to compete with the commercial water companies, even if it makes the distribution of their water slightly more expensive? Are green or clean bottles a unique selling property in this highly competitive market? Would customers be willing to pay a bit more, because the water coming from an Islamic boarding school brings more blessing than that from a commercial company, and green or clean alternatives to plastic bottles do justice to Nadhlatul Ulama's commitment to reduce plastic waste? Here, too, we can make use of the theory of the dialogic self: weighing medical, commercial, and religious considerations.

\section{Conclusion}

In the introduction, I asked what a social study of religion can contribute to the theory and practice of environmentalism in Indonesia, and what this signifies for future research in this field. My answer is that the social study of religion can help to conceptualize religion as a social construct and move beyond reified understandings of religion.

I purposely speak about religion here, and not about faith or belief, to avoid a theological debate. An elaboration on the consistency or inconsistency between the empirical (social-scientific) and normative (theological) study of religion (Bagir and Martiam 2016) goes beyond the scope of this article.

The Indonesian Government wants faith-based organizations to be included in water- and waste management and faith-based organizations such as Nadhlatul Ulama and Muhammadiyah committed themselves to collaborate with the government in this respect. However, often the understanding of religion is naïve on both sides. Scholars of religion can 
make them aware of the fact that on the one hand religion has an added value and makes a difference, and that on the other hand religion is complex, diverse, and ambiguous.

For future research in this field, I propose to elaborate more on the ambivalence of religion and to use the dialogical self theory to deal with the dilemma between norms and practices that Bagir and Martiam (2016) wrote about earlier, the tension between theological and technological voices, the faith-based underpinnings of 'small' ('back to nature') and 'smart' (circular economy, green technology) solutions for ecological challenges, and the gap between the religion that is lived in every-day lives and the religion that is learned in schools and mosques, drawing on classical sources.

\section{References}

Aoki, Takenobu. 2016. "Islamic NGOs on Environmental Problems in Indonesia". Pp. 69-86 in NGOs in the Muslim World: Faiths and Social Services, edited by Susumu Nejima. London: Routledge.

Asian Development Bank. 2016. Indonesia: Country Water Assessment. Mandaluyong City: Asian Development Bank. Retrieved 19 July 2021 (https://www.adb.org/sites/default/files/institutionaldocument/183339/ino-water-assessment.pdf).

Bagir, Zainal Abidin and Najiyah Martiam. 2016. "Islam: Norms and Practices". Pp. 79-87 in Routledge Handbook of Religion and Ecology, edited by Willis J. Jenkins, Mary E. Tucker, and John Grim. London: Routledge.

Ballon, Pieter and Dimitri Schuurman. 2015. "Living Labs: Concepts, Tools and Cases", Info 17 (4), https://doi.org/10.1108/info-042015-0024.

Central Board of Muhammadiyah. 2016. The Islamic View of Water Use and Conservation. Yogyakarta: Central Board of Muhammadiyah.

Citarum Roadmap and Investment Program. 2017. Retrieved 19 July 2021 (http://citarum.org/en/citarum-knowledge-2/publication/ cita-citarum-photo-report/89-investment-program-summary-ipsummary-english/file.html).

Deputy for Public Participation and Environmental Communication. 2014. Environmental Education in Indonesia. Ministry of Environment, The Republic of Indonesia. Retrieved 19 July 2021 (https://www.epa.gov.tw/public/Attachment/78717114334. pdf). 
Douglas, Mary. 1966. Purity and Danger. An Analysis of Concepts of Pollution and Taboo. London: Routledge and Kegan Paul.

Editorial Board. 2019. "A Dish of Microplastics". The Jakarta Post, January 28. Retrieved 19 July 2021

(https://newgelora.thejakartapost.com/academia/2019/01/28/adish-of-microplastics.html).

Fahrurrazi. 2019. "To Be Ecological Is to Become Pluralist: Inclusive Religious Education at The Eco-Pesantren Ath-Thaariq, West Java". Studies in Interreligious Dialogue 29(1): 23-42, https://doi. org/10.2143/SID.29.1.3286453

Faizin, Muhammad. 2019. "Ini Hukum Tidak Mengelola dan Membuang Sampah Sembarangan". NU Online, February 28. Retrieved 19 July 2021

(https://www.nu.or.id/post/read/103151/).

Festinger, Leon. 1957. A Theory of Cognitive Dissonance. Stanford, CA: Stanford University Press.

Gade, Anna M. 2019. Muslim Environmentalism: Religious and Social Foundations. New York: Columbia University Press.

Hermans, Hubert. 2018. Society in the Self: A Theory of Identity in Democracy. Oxforf: Oxford University Press.

Jotzo, Frank. 2012. "Can Indonesia Lead on Climate Change?" In Anthony Reid, ed., The Repositioning of Asia's Third Giant. Singapore: ISEAS Publishing.

Lamb, Kate. 2018. "Preaching Against Plastic: Indonesia's Religious Leaders Join Fight to Cut Waste. The Guardian, June 7.

Retrieved 19 July 2021 (https://www.theguardian.com/ world/2018/jun/07/indonesia-plastic-rubbish-religious-leadersjoin-fight-to-cut-waste).

"List Merk Air Minum Mineral Produksi dari Kaum Muslim (2020), Hilyah.id, 6 November. Retrieved 19 July 2021

(https://hilyah.id/list-merk-air-minum-mineral-produksi-darikaum-muslim/).

Mangunjaya, Facruddin et al. 2015. "Faiths from the Archipelago. Action on the Environment and Climate Change". Worldviews 19: 103122. 
Mubarok, Zaki. 2019. "Nahdlatul Ulama's Green Agenda". The Jakarta Post, February 26. Retrieved 19 July 2021 (https://www. thejakartapost.com/academia/2019/02/26/nahdlatul-ulamasgreen-agenda.html).

NF, Syakir. 2019. "Upaya NU Tanggulangi Sampah Plastik“. NU Online, March 3. Retrieved 19 July 2021

(https://www.nu.or.id/post/read/103316/upaya-nu-tanggulangisampah-plastik).

Petrlik, Jindrich et al. 2019. "Plastic Waste Poisons Indonesia's Food Chain“. Retrieved 19 July 2021

(https://ipen.org/sites/default/files/documents/indonesia-eggreport-v2_0-web.pdf).

Saptaningtyas, Haryani. 2020. This is Our Belief Around Here": Purification in Islamic Thought and Pollution of Citarum River in West Java. Münster: LIT Verlag.

Stringer, Martin. 2008. Contemporary Western Ethnography and the Definition of Religion. London: Continuum International Publishing Group.

Wijsen, Frans and Haryani Saptaningtyas. 2016. "Religion and Environment: Pollution of Citarum River and Purification in Islamic Thought". Pp.125-154 in Teologi yang Membebaskan dan Membebaskan Teologi, edited by R. Setio \& W. Wibowo. Yogyakarta: Universitas Kristen Duta Wacana.

Wijsen, Frans and Haryani Saptaningtyas. 2021. "Cleanliness is Part of Faith: Religious Values in Water Management". Pp. 163-182 in Varieties of Religion and Ecology: Dispatches from Indonesia, edited by A. Bagir, M. S. Northcott, and F. Wijsen. Münster: LIT Verlag. 
